\title{
CROATIAN POLICY TOWARDS THE NATO ENLARGEMENT IN THE WESTERN BALKANS
}

\author{
Ružica Jakešević, PhD, \\ Faculty of Political Science, University of Zagreb \\ E-mail: ruzica.jakesevic@fpzg.hr \\ Dario Malnar, Ph.D, \\ Independent researcher, \\ E-mail: malnar.zg@gmail.com \\ Siniša Tatalović, Ph.D, \\ Faculty of Political Science, University of Zagreb \\ e-mail: sinisa.tatalovic@fpzg.hr
}

\begin{abstract}
This paper analyzes Croatia's policy towards NATO enlargement in the Western Balkans. After the Cold War, NATO has undergone major changes, which included organizational and strategic adjustments to new conditions in international relations, as well as the expansion to new countries. These processes can be viewed as an effort aimed at positioning NATO as inevitable actor in global security processes on the one hand, and at widening the trans-Atlantic security community on the other. Its actions in the post-Cold war period have not been limited to the territory of the Member States only (collective defence), but have been predominantly carried out in the wider environment in which conflicts occurred (collective security). One such area was the Western Balkans, where NATO had decisive impact on stopping the conflict and the establishment of peace and stability. This was particularly true in the case of Bosnia and Herzegovina and Kosovo. NATO enlargement to the countries of Southeast Europe has significantly affected the improvement of the security situation in the region. NATO
\end{abstract}




\section{Seccurity}

membership of Croatia, Albania and eventually Montenegro serve as the case in point. Croatian position is specific, not only due to its geo-strategic position, but also because of its special interest in stability and Euro-Atlantic perspective of Bosnia and Herzegovina. The paper is based on the hypothesis that the expansion of NATO to the countries of the Western Balkans has had positive impact on the stability and security of the region, which is why Croatia strongly advocates further NATO enlargement to the rest of the countries of the region (to those which declared NATO membership as their foreign and security policy objective). This hypothesis will be elaborated through the analysis of NATO strategic documents and Croatian foreign and security policy, especially those parts that are related to the Western Balkans.

Key words: NATO enlargement, Croatia, Western Balkans, security community, security policy

\section{Introduction}

The end of the Cold War has led to a significant shift in global security processes, whereby those processes have been partly related to the redefinition of the role of certain actors in international relations. The range of actors on the international political scene in the post-Cold War era has expanded considerably, and today it encompasses a number of subjects that can have either a positive or negative impact on the international security environment. Among the actors that started the process of redefining their character, mission and scope of their tasks in the post-Cold War period were both the EU and NATO. These two regional organizations (whose geneses of development during the Cold War were clearly functionally distinctive) are the main actors of the (pluralistic) security community that encompasses the trans-Atlantic area since the late 1950s (Cottey, 2014: 168). For both organizations the end of the Cold war marked the turning point and the beginning of the new formative period, in which both the EU (EC at that time) and NATO began to build new mechanisms and take on new functions, while at the same time intensively searched for ways of their mutual functional harmonization.

Building up of the EC's security component was almost a complete novelty in the development of the Community, whereby Common Foreign and Security Policy has 
been developing only since the Maastricht Treaty (1992) as one of the aspects of deeper integration between the Member States. On the other hand, NATO, which had clearly defined its security role during the Cold war (collective defence), was primarily faced with the need of defining and justifying its further existence in the new strategic environment. Civen that the non-integrated part of the European continent sank into negative security processes and conflicts (former Yugoslavia) in the early 1990s, the space for the use and testing of NATO's redefined capacities was opened. The NATO's task of defending the territory of its member states was thus complemented with the increased focus on out-of-area operations and enlargement as the model for improving security conditions. "Enlargement of NATO and the European Union has been the way towards a Europe whole, free and at peace" (NATO, 2017a).

Starting from such orientation, NATO has actively participated in putting an end to the conflicts in the Western Balkans, primarily in resolving conflicts and later in the institutional development of Bosnia and Herzegovina and Kosovo. From the NATO perspective "the Western Balkans is a region of strategic importance "where NATO n....remains fully committed to the stability and security, as well as to supporting the Euro-Atlantic aspirations of countries in the region. Democratic values, rule of law, domestic reforms, and good neighbourly relations are vital for regional cooperation and for the Euro-Atlantic integration process. The Alliance will continue to work closely with the Western Balkans to maintain and promote regional and international peace and security"(NATO, 2016a).

The Western Balkans is a region marked by political and institutional weaknesses and disturbances, undefined interethnic relations, corruption and organized crime. This is also the area of interest for non-regional entities that are often of a destabilizing character and the area of proxy confrontation of the most important actors of international politics, which further destabilizes and makes the area unsafe. Due to these reasons, this area has specific security significance and is of a special interest for NATO. The NATO enlargement process in the Southeast Europe, as well as the membership of Hungary, Romania and Bulgaria, is important from the aspect of establishing territorial connection between Greece and Turkey and the rest of the Alliance. Subsequent membership of Croatia and Albania in the Alliance has turned the 
Western Balkans ${ }^{215}$ into some kind of security-undefined "island" surrounded by NATO members. However, this is not the final state. The prospects of the Western Balkan states for joining the Alliance are open, as was confirmed by the declaration of "Open door" policy at the NATO Summit in Warsaw (NATO, 2016a), as well as by the expected membership of Montenegro in the near future. Serbia, which has declared the principle of military neutrality, is also encouraged to strengthen its partnership and cooperation with the Alliance (NATO, 2014).

Such an approach in which Western Balkans, although still burdened with security challenges and destabilization processes of internal and external character, primarily stemming from Bosnia and Herzegovina, Kosovo and Macedonia, is not left aside is particularly important since it enables the parallel development of security and stability processes, additionally promoted by the EU. It is often stated that "the enlargement perspective has played and continues to play a crucial role in the regional stabilisation and pacification processes" (Grimm, 2007).

As a NATO member located near the Western Balkans region, the Republic of Croatia considers this area extremely important and thus is very interested in regional processes. This interest stems from several reasons: apart from the historical ones, the most important are geostrategic, because Croatia, as well as Hungary, simultaneously leans on the territory of the Western Balkans and on the territory of other member states and the depth of the area of the Alliance. Through Bosnia and Herzegovina, the Western Balkans is deeply embedded in the territory of the Alliance and almost divides the northern and southern parts of Croatia. Additionally, Croatia has specific relations with individual countries of this region, particularly Bosnia and Herzegovina, which is extremely important in terms of regional security.

Membership of the Western Balkans countries in NATO and the consequent security integration of this area with other member states, is thus of utmost importance for the Croatian national security. This is also the starting point of Croatia's policy towards NATO's enlargement to the Western Balkans, which will be analyzed in this paper. Authors have set the following hypothesis: The expansion of NATO to the countries of the Western Balkans has had positive impact on the stability and security of the region, which is why Croatia strongly advocates further NATO enlargement to the

${ }^{215}$ Western Balkans encompasses Albania, Bosnia and Herzegovina, Montenegro, Kosovo, Macedonia and Serbia. 


\section{Security}

rest of the countries of the region (to those which declared NATO membership as their foreign and security policy objective).

\section{Western Balkans countries in the NATO enlargement process}

All Western Balkans countries, except Kosovo, have established institutionalized cooperation with NATO. In addition, all countries in this region, apart from Serbia, consider membership of the Alliance as a desirable framework for improving their own security, but also for the confirmation of their own statehood and independence. The three Western Balkan states are candidates for NATO membership (Montenegro, Bosnia and Herzegovina and Macedonia), and Montenegro is expected to become a full member soon after the ratification process has ended.

Western Balkans countries have established different forms of cooperation or integration with NATO. Albania has been a member state since 2009 and therefore it is not the subject of this analysis, which focuses on Bosnia and Herzegovina, Montenegro, Kosovo, Macedonia and Serbia - that is, the states surrounded by NATO members and still undefined in terms of their security status. In addition, these countries have numerous individual characteristics that determine and significantly hamper a coherent approach to regional security through the process of integration into NATO membership. These are states that were exposed to military actions of NATO at some point: the 1993 operation "Deny Flight", which had the task of imposing a no-fly zone in Bosnia and Herzegovina, was the first NATO out-of-area operation; or the operation "Allied Force", which was the bombing campaign of the Federal Republic of Yugoslavia, primarily Serbia, during 78 days in 1999, the aim of which to stop the violence of Serbian authorities in Kosovo.

In some countries of the region, NATO was or still is engaged in peacekeeping operations. Signing of the Dayton Accords in 1995 was followed by NATO engagement in Bosnia and Herzegovina through Implementation Force (IFOR), which transformed into Stabilization Force (SFOR) in 1996 and lasted until 2004. Operation Allied Force has led to the separation (and independence) of Kosovo and the deployment of peacekeeping forces Kosovo Force (KFOR), which are still operational under the auspices of NATO. 


\section{Seccurity}

Numerous contradictions and the character of its political system, which are the consequence of the 1990s conflict, have determined the dynamics and the content of activities related to the NATO integration processes in Bosnia and Herzegovina. Namely, political representatives of Serbs in this country, in solidarity with Serbia on the one hand and still calculating the final state organization and possible secession of their entity on the other hand, are obstructing the progress of Bosnia and Herzegovina towards NATO. That is why Bosnia and Herzegovina has not yet made a further step towards the Membership Action Plan after joining the Partnership for Peace in 2006, despite the appeals from NATO216.

Unlike Bosnia and Herzegovina, Montenegro, which also joined the Partnership for Peace in 2006, has currently been in the final phase of the process and is expected to enter the Alliance during 2017. It should be emphasized that the Republic of Croatia provides significant support to Montenegrin membership, including through the development of security cooperation and the transfer of experience gained within NATO missions in Afghanistan, ISAF and Resolute Support. Since 2010, members of the Montenegrin contingent have been deployed within the ISAF (currently Resolute Support) together with the Croatian military forces.

Kosovo's independence is largely a result of NATO's action. Since some NATO members have still not recognized Kosovo, it's not possible to start formal integration processes. However, other than those within the KFOR mission, NATO has additional tasks in Kosovo. Since 2008, NATO has been supporting the establishment of the Kosovo Protection Corps and the subsequent transformation of the Kosovo Security Force (KSF) and structures for the civilian oversight of KSF (NATO, 2017b)

Macedonia, which had formalized its path to membership already in 1995 when it joined the Partnership for Peace, is in a specific situation. It was expected that this country would join the Alliance in 2009 together with the Republic of Croatia and Albania. However, this did not happen because at the 2008 NATO summit in Bucharest Greece made its membership conditional on a change of name, and consequently NATO adopted the decision that Macedonia would receive an invitation to the membership

\footnotetext{
${ }^{216}$ In 2010 Bosnia and Herzegovina received an invitation to join the Membership Action Plan (MAP). The condition was to transfer the prospective military property owned by one of the entities to the Bosnia and Herzegovina as the state. (NAT0, 2017d). See also: Secretary General: NATO is committed to peace and stability in the Western Balkans, 2 Feb. 2017. (NATO, 2017e).
} 


\section{Seccurity}

after these two states had reached an agreement on the name (NATO, 2017c). At that point the accession process was completely stopped, while the solution to the dispute over the name of Macedonia is still not certain.

Finally, it is necessary to include Serbia into this analysis, as the country which was a direct object of NATO's activities in 1999. Due to this fact, as well as the subsequent NATO's engagement on Kosovo, which is not recognized as an independent state by Serbia, this country has adopted a resolution that, among other things, declares military neutrality (National Assembly of the Republic of Serbia, 2007) and defines the substance of its relation with the Alliance. NATO certainly does not look with approval the Russian influence in Serbia, although this is not publicly pronounced. Serbia, at least for the time being, does not aspire to membership in NATO and the Alliance accepts this. However, considering that Serbia will not be able to continue this policy of "sitting on two chairs at the same time" in the long run, NATO constantly develops its cooperation with this country. The result of this development was the admittance of Serbia into Partnership for Peace program in 2006, and the cooperation was further deepened in 2015 through the Individual Partnership Action Plan (IPAP) (NATO, 2016b).

\section{The Development of the Croatian policy towards the NATO enlargement to the Western Balkans}

There are several events, which represented major turning points in defining regional security in Southeast Europe, such as: termination of the Homeland War and the peaceful reintegration of the Eastern Slavonia and the Danube region in the Republic of Croatia; the end of war in Bosnia and Herzegovina; and the overthrowing of Slobodan Milošević regime in 2000 in Serbia. These changes significantly influenced the shift in the Croatian security paradigm. Therefore, the year of 2000, when the seventh Croatian government came into power, ${ }^{217}$ will be taken as the starting point for the analysis of the Croatian policy towards the NATO enlargement to the states of the

217 Seventh government under the Prime Minister Ivica Račan took the office on 27 January 2000. 


\section{Seccurity}

Western Balkans. It is also the moment when the mentioned changes in the security paradigm were initiated.

The explanation of Croatia's policy on this issue in this paper consists of the analysis of the Croatian governments' programs as their fundamental political documents since 2000 as well as the analysis of the still valid National Security Strategy (2002). New security paradigm was based on a shift towards strengthening cooperation in seeking solutions for further stabilization of the region and enhancing national and regional security.

The Kosovo crisis in 1999 prompted the international community to reassess its engagement in this area and to adopt a more comprehensive approach to fostering security and stability in the region. This was reflected in launching the NATO Initiative for South East Europe, as well as the Stability Pact for Southeast Europe. Since then, NATO's contribution to building security and stability in South-East Europe has expanded from peacekeeping operations to promoting security cooperation in the region (NATO, 2006: 245).

It should be borne in mind that the Republic of Croatia defined its approach to NATO enlargement to the region from two essentially different positions: from the position of the aspirant to NATO membership until 2009, and then from the position of the member state since 2009. The basic elements of the first approach can be found in the 2000 Government program, which estimated that "the regional environment of Croatia was still unstable ..." (The Government of the Republic of Croatia, 2000: 30). The section that defines the fundamental objectives states that "strengthening relations with neighbouring countries and joining the European Union and NATO will demonstrate the commitment to Euro-Atlantic policy and the readiness of Croatia to accept the role of the most stable partner in the region" (The Government of the Republic of Croatia, 2000: 5-6).

These statements provide the necessary elements for determining the approach to national security:

1. Joining the membership of the EU and NATO and commitment to their policies

2. Strengthening relations with neighbouring countries

3. Positioning of the Republic of Croatia as the most stable partner in the region. 
A clear commitment of the Republic of Croatia to act in its neighbourhood is also confirmed by another statement in the Government program, that "... the government will encourage all the forces of peace and cooperation and encourage good neighbourly relations" (The Government of the Republic of Croatia, 2000: 30), and "improve stability by acting in line with the EU and NATO policies, even before the formal membership". ${ }^{218}$ Such approach is complementary to NATO's approach to stabilization of the region. Additionally, an active approach to regional cooperation and strengthening regional security and stability was also encouraged by the EU criteria in the Croatian negotiation process. ${ }^{219}$ However, at that point Croatia did not identify stabilization of the Western Balkans with the membership of the states of the region in the NATO. Instead, its policy towards the region was defined at two complementary levels: the national one, and the level of NATO approach.

Such an approach was a prerequisite for the institutionalization of relations with NATO, which started with the accession to the Partnership for Peace program in $2000 .{ }^{220}$ Another significant step in joining NATO occurred in May 2002, when Croatia was invited to participate in the Membership Action Plan (MAP). Immediately before that, Croatia adopted its first National Security Strategy. This fundamental national security strategic document has confirmed that the accession to the EU and NATO are among the most important national goals, and that Croatia fully shares and supports the values and goals underlying the EU and NATO (National Security Strategy, 2002: 2). This strategy extensively deals with security threats, which are stemming from unconsolidated transition countries of the Western Balkans. It also emphasizes that Croatian security actions will keep the regional focus, since "security challenges and

\footnotetext{
218 Ever since 1996, the EU acted through the prism of regional approach, which also encompassed the Republic of Croatia. At that period, Croatia was politically defined as part of the "Western Balkans". (The Government of the Republic of Croatia, 2000: 10

219 Among other things, EU requirements towards Croatia included promoting regional cooperation, development of good neighbourly relations, fulfilling the obligations under the international law, strengthening security and stability in Europe, and especially in Southeast part of the continent, through cooperation in the areas which are integral parts of the CFSP. (Božinović, 2003: 111

${ }^{220}$ Along with the accession to the Partnership for Peace in 2000, Croatia was also admitted to the Euro-Atlantic Partnership Council and obtained the status of Associate Member of the NATO Parliamentary Assembly.
} 


\section{Seccurity}

threats in the region, regardless of their scope, are more important for the national security of the Republic of Croatia than regional challenges and threats in other parts of the world" (National Security Strategy, 2002: 9). Stabilization of the regional environment is perceived through national activities, which should be coordinated with NATO policies and standards and not through the membership of the region in the Alliance, although it states that "...the NATO enlargement would also expand the area of rule of law, democracy, human rights and other shared values." ${ }^{221}$ Thus, it can be argued that Croatia defined its national security concept in redefined security environment at the beginning of the $21^{\text {st }}$ century by focusing on the NATO (and EU) accession and active engagement in building regional security.

Such orientation was additionally confirmed in the program of the ninth Croatian government, ${ }^{222}$ which also expressed that "the government welcomes the EU decision reached at the 2003 Thessaloniki Summit, which opens a clear perspective for all countries in this part of Europe for full membership in the European Union" (Government of the Republic of Croatia, 2003: 36). The permanent stabilization of the region was thus linked to European integration processes.

The program of the successive tenth government kept the same tone. It contained some very indicative statements, which repeatedly confirm that the membership of NATO and the EU stand as the primary foreign policy goals, as well as that Croatia aims to act as the actor of lasting peace, stability and security "in the stable environment of the countries of the region which share identical efforts in their individual paths towards membership (Government of the Republic of Croatia, 2008: 7). Moreover, the program reflects strong belief that only European and trans-Atlantic perspective provide the only framework and stimulus for resolving remaining open issues in the Southeast Europe. Finally, it states that "Croatia will continue to promote

\footnotetext{
${ }^{221}$ National Security Strategy of the Republic of Croatia, Official Gazette, No. 32/02, p.10.

222 "In a changing world that is entering a new era of international relations, Croatia has important place and role. It cannot and will not be left out in creating a new European political, economic and security landscape. Its contribution to shaping lasting peace, stability and development in the Southeast Europe is also indispensable. Permanent regulation of the system of security and stability in this part of Europe is possible only in accordance with the principles of justice, law and equality, with the respect for interests of all the countries and peoples, and with the consensus of the international community. (The Government of the Republic of Croatia, 2003: 1).
} 
policy of good neighbourly relations in Southeast Europe, which stems from the European vision and principles, as well as addressing the remaining open issues in order to secure the Euro-Atlantic perspective for this region" (Government of the Republic of Croatia, 2008: 105).

In this way, the Republic of Croatia created a consistent security concept based on an approach that strengthens national, regional and European security through the integration of Western Balkans into NATO and the EU. This government program was ongoing at the time of the NATO Summit in Bucharest 2008, when the Republic of Croatia received an invitation for NATO membership and became the member of the Alliance on April 1, 2009. Subsequent government programs continued to support the region's inclusion in the Euro-Atlantic political and security framework. ${ }^{223}$

Finally, the policy of the recent fourteenth Croatian government is unambiguous in that it contends that one of its fundamental foreign policy principles is providing support to Bosnia and Herzegovina and other states in Southeast Europe in their efforts to join the membership of the EU and NATO. The Government program emphasizes that Croatia is positioning itself as a key creator and promoter of the European and trans-Atlantic policy in Southeast Europe and that its actions towards non-integrated states of the region "will support their efforts in fulfilling necessary standards for the EU and NATO membership, whereby the European perspective of Bosnia and Herzegovina presents the key foreign policy goal and strategic interest for the Republic of Croatia" (The Government of the Republic of Croatia, 2016: 36).

The foreign policy section of the election program of the current Croatian president states that "Croatian foreign policy has specific tasks and national interests in Southeast Europe", that Croatia "will help international community and the countries of the region, which are currently not members of the Euro-Atlantic integrations, in reaching the necessary standards" and that it will "take over the implementation of the integration policy towards the countries in its neighbourhood". ${ }^{224}$ This commitment was confirmed in the President's speech at the Munich Security Conference 2017, when Ms.

223 "Croatia has greater and more specific interests than the EU member states in achieving sustainable political and economic stability in Southeast Europe, which is our immediate neighbourhood. The benefits of our membership in the European Union will not be complete until other countries in the region become members of the Union." (The Government of the Republic of Croatia, 2011: 43).

${ }^{224}$ Kolinda Grabar Kitarović, The Election program "For Better Croatia", p. 34-35. 


\section{Seccurity}

Grabar-Kitarovic emphasized the issue of NATO's and EU's interest for the states in Southeast Europe. The loss of interest for Southeast Europe was accompanied by the revival of old nationalist and expansionist visions, strengthening of radical Islamism and the involvement of third countries, especially Russia, whose interference threatens the integration of the countries of the region into the EU and NATO. ${ }^{225}$

There are at least three reasons why Croatia supports the strengthening of cooperation between its neighbouring states and NATO:

1. Strengthening political relations involves the implementation of reforms that are directly related to democratization and transparency of the armed forces systems;

2. Strengthening cooperation involves a wider range of reforms (minority issues, human rights, justice affairs ...), which are also associated with the criteria for the EU membership;

3. Commitment to regional cooperation reduces the risk of regional tensions (Ministry of Foreign Affairs, 2017).

For all of these reasons, and due to NATO's reduced interest for Western Balkans, Croatia needs to continue its active approach in promoting NATO enlargement in this region and to help these countries to fulfil all the membership requirements. As a NATO member state, Croatia actively participates in the implementation of the Alliance's cooperation with the countries of the Western Balkans, which covers five core areas:

1. Security cooperation 226

2. Defence and security sector reforms, which are the core of cooperation

${ }^{225}$ Russia's involvement is a threat to EU and NATO enlargement [Miješanje Rusije je prijetnja proširenju EU i NATO-a], 16. 02. 2017. Accessible at:

http://hr.nlinfo.com/a179968/Vijesti/Grabar-Kitarovic-Mijesanje-Rusije-je-prijetnja-prosirenjuEU-i-NATO-a.html (23 February 2017).

${ }^{226}$ Security cooperation primarily focuses on developing military forces' capabilities to work/act together with the forces of NATO countries and other partners, particularly in peacekeeping operations and crisis management operations. Participation in joint planning, training and military exercises within the Partnership for Peace program is considered particularly important. One of the obvious obligations of the aspirant states was the obligation to engage in the NATO International Security Assistance Force (ISAF) and later Resolute Support mission in Afghanistan. All the countries of the region, except Serbia, participated or have been currently participating. 


\section{Seccurity}

3. Planning for emergency situations

4. Facilitating public access to information on cooperation with NATO

5. Scientific security cooperation.

Croatian Armed Forces have been participating in the KFOR ${ }^{227}$ peace support operation in Kosovo since July 2009 and have made a practical contribution to NATO's efforts in maintaining security, as well as in developing Kosovo's security system in line with NATO standards, which is an essential prerequisite for future cooperation and integration of Kosovo into NATO.

Therefore, all of the above mentioned implies that Croatia applies comprehensive approach to NATO enlargement to the Western Balkans. Such an approach is founded upon the previously mentioned three specific interests, whereby the progress of these states towards the membership of NATO is not seen only as the result of the Alliance's unilateral effort or bilateral cooperation. Sustainability of stability and security cooperation in the region requires a wide range of adjustments in order to overcome the obstacles that exist at the national, bilateral and regional levels, and which go beyond the framework of NATO's action. This refers to numerous weaknesses that endanger the stability and security of the region, such as unresolved inter-ethnic relations affecting the stability of individual countries (Bosnia and Herzegovina, Kosovo, Macedonia), open bilateral issues (Kosovo-Serbia, GreeceMacedonia), and the activities of non-regional actors (Russian Federation), which negatively affect the integration processes. In other words, states in the region must develop good-neighbourly relations and establish and maintain functional regional cooperation if they want to become members of NATO and the EU (Čehulić Vukadinović, 2014: 702).

For this reason, it is important to apply complementary approach in which NATO's efforts are complemented with the process of cooperation between these countries and the EU, as well as with regional cooperation, which articulates the specificities of individual states and the region itself. In the consideration of EuroAtlantic and regional cooperation, it is important to keep in mind bilateral relations between the Western Balkan states. Very often, these bilateral relations and different forms of cooperation were developed under the external pressures, which resulted in an illusion of far better relations than they actually were. Therefore, it seems that the

${ }^{227}$ According to the decision of the Croatian parliament (15 July 2008). 


\section{Seccurility}

wider community, such as NATO, can provide a good framework for resolving regional disputes and security threats.

\section{Conclusion}

As a NATO member, but also for the reasons of its own national security, the Republic of Croatia has been continuously pursuing a constructive policy towards the region, especially in the case of providing support to Bosnia and Herzegovina on its way to EU and NATO membership. Furthermore, Croatia develops partnership relations with Montenegro and is one of the key states on the Montenegrin path towards NATO membership. With the membership of Montenegro in the NATO, all the countries surrounding the Adriatic Sea, except Bosnia and Herzegovina, will be members of the Alliance, which is very important from the perspective of national security of the Republic of Croatia.

Considering its geopolitical position, the region of Southeast Europe is where the interests of key international political actors, such as US, the EU, Russian Federation and even China, are colliding. Therefore, it is important to apply appropriate policies as a means of mediation and harmonization of different interests.

In this process, relations between Croatia and Serbia, which are developed especially in the field of economy, have a crucial role, which creates a good prerequisite for the development of political and security cooperation. However, although Serbia declares that the EU membership is its strategic goal, it has to provide a clear response to its complex security paradigm. Namely, although Serbia had declared the policy of military neutrality, it also signed some contracts on military cooperation with Russian Federation, ${ }^{228}$ regularly conducts joint military exercises, and there are also some significant donations in Russian military equipment, which raises doubts about Serbian military neutrality. The existing military cooperation between these two states is inconsistent with the EU Common Foreign and Security Policy and can present serious

\footnotetext{
${ }^{228}$ Agreement between the Government of the Republic of Serbia and the Government of the Russian Federation on military cooperation (signed in Belgrade on 13 November 2013) and Agreement between the Government of the Republic of Serbia and the Government of the Russian Federation on military-technical cooperation (signed on 14 October 2014).
} 


\section{Seccurity}

obstacle to Serbian negotiation process with the EU. In such circumstances, it is important to keep the continuity of compatibility between Croatian security policy and the EU and NATO partners.

Besides NATO which represents the "hard power, the analysis of the security position of the Western Balkans has to include the role of the EU as an entity which possesses significant "soft power" mechanisms. The roles of two actors are complementary, whereby the EU serves as very important actor for the stabilization of the region and in providing response to the influence of other non-regional actors. ${ }^{229}$ Besides the EU, NATO, US and the Russian Federation, Chinese policy towards the region, embodied in the $16+1$ initiative, has to be taken into account, as well as the increasing interest of Turkey for the regional matters. Turkish actions in the region are increasingly unilateral, based exclusively on Turkish national interests, uncoordinated with NATO partners, and very often quite opposite to EU and NATO policies in the region. $^{230}$

The result of the Western Balkans' integration into EU and NATO (except Serbia) will depend on the readiness of all the external actors (US, EU, NATO, Russian Federation, China and Turkey) to encourage positive processes (in the area of economy, development of democratic capacities, etc.), whereby Croatia has to continue with the constructive and active contribution.

${ }^{229}$ The EU aims to promote peace, stability and economic development in the Western Balkans and open up the prospect of EU integration. European Parliament, The Western Balkans, Accessible at:

http://www.europarl.europa.eu/atyourservice/en/displayFtu.html?ftuld=FTU_6.5.2.html (30 March 2017).

230 Recent statements of the Turkish president Erdogan in which he accuses EU leaders for Nazism, the Crusader Alliance and threatens the security of the people from the West.

See more at: http://www.avaz.ba/clanak/283957/erdogan-u-sukobu-s-jos-jednom-zemljom-izeu-na-rubu-su-rata?url=clanak/283957/erdogan-u-sukobu-s-jos-jednom-zemljom-iz-eu-na-rubusu-rata\#sthash.9WL6nOWa.dpuf (30 March 2017). 


\section{Securiagues rity}

\section{References}

1. Božinović, D. (2003) "Hrvatska i Europska unija“ in: Međunarodna politika, Vol. LIV, No. 1111, 2003.

2. Cottey, Andrew (2014) "Europe" in: Sperling, James, Handbook of Governance and Security. Edward Elgar, UK; Northampton, MA, USA.

3. Čehulić Vukadinović, L. (2014) "Hrvatski pogled na euroatlantizam na Zapadnom Balkanu“ in: Bosna i Hercegovina i euroatlantske integracije (zbornik radova), Pravni fakultet Bihać. Accessible at:

https://ssrc.ibu.edu.ba/assets/ssrc/userfiles/files/ZBORNIK-TOM-II.pdf (9 Febroary 2017)

4. Grabar Kitarović, Kolinda. (2014) Izborni program "Za bolju Hrvatsku". Accessible at:

http://cevipol.ulb.ac.be/sites/default/files/Contenu/Cevipol/kgk_za_bolju_hrv atsku.pdf (9 February 2017)

5. Grim, Karin. (2007) Integrating the Western Balkans into NATO and the EU: Challenges, Expectations and Needs. DCAF, SSR-WG Workshop Paper.

Accessible at:

https://www.files.ethz.ch/isn/142896/pfp_rssee_budva_policy.pdf (20 February 2017)

6. Ministarstvo vanjskih i europskih poslova. (2017) Prioriteti i aktivnosti RH kao članice NATO-a. Accessible at:

http://www.mvep.hr/print.aspx?id=2355\& itemld=0\&lang=1 (9 February 2017)

7. NATO. (2006) Handbook, Accessible at:

http://www.nato.int/docu/handbook/2006/hb-cr-2006/part7.pdf (19 February 2017)

8. NATO. (2014) Wales Summit Declaration, Issued by the Heads of State and Government participating in the meeting of the North Atlantic Council in Wales. Accessible at:

http://www.nato.int/cps/en/natohq/official_texts_112964.htm (30 April 2017)

9. NATO. (2016a) Warsaw Summit Communiqué, Issued by the Heads of State and Government participating in the meeting of the North Atlantic Council in Warsaw 8-9 July 2016. Accessible at:

http://www.mfa.gov.pl/en/foreign_policy/nato_2016/warsaw_summit_commun 
ique;jsessionid=9A50BA7C1ADE137FD978FE160D51F61F.cmsap6p (30 April 2017)

14. NATO. (2016b) Joint press point, 26 Nov 2016. Accessible at: http://www.nato.int/cps/en/natohq/opinions_137794.htm (9 April 2017)

15. NATO. (2017a) Speech by NATO Secretary General Jens Stoltenberg to university students in Sarajevo, Bosnia and Herzegovina, 6 Feb. 2017 http://www.nato.int/cps/ru/natohq/opinions_140517.htm (22 March 2017)

16. NATO. (2017b) NATO's role in Kosovo. Accessible at: http://www.nato.int/cps/en/natohq/topics_48818.htm (9 February 2017)

17. NATO. (2017c) NATO: Relations with the former Yugoslav Republic of Macedonia. Accessible at: http://www.nato.int/cps/en/natohq/topics_48830.htm (9 February 2017)

18. NATO. (2017d) Relations with Bosnia and Herzegovina. Accessible at: http://www.nato.int/cps/en/natohq/topics_49127.htm (9 February 2017)

19. NATO. (2017e) Secretary General: NATO is committed to peace and stability in the Western Balkans, 2. Feb 2017. Accessible at: http://www.nato.int/cps/en/natohq/news_140544.htm?selectedLocale=en (9 February 2017)

20. Republika Hrvatska. (2002) Strategija nacionalne sigurnosti Republike Hrvatske, NN32/02.

Accessible at: http://narodne-

novine.nn.hr/clanci/sluzbeni/2002_03_32_692.html (10 February 2017)

21. Vlada Republike Hrvatske. (2000) Program rada Vlade Republike Hrvatske za razdoblje 2000.-2004. godine. Accessible at:

http://digured.srce.hr/arhiva/10/31637/Program\%20rada\%20Vlade\%2020002004.pdf (10 February 2017)

22. Vlada Republike Hrvatske. (2003) Program Vlade Republike Hrvatske u mandatnom razdoblju 2003.-2007. Accessible at: http://digured.srce.hr/arhiva/18/5093/Program_vlade_RH_2003-2007.pdf (16 February 2017)

23. Vlada Republike Hrvatske. (2008) Program Vlade Republike Hrvatske za mandat 2008.-2011. Accessible at: http://digured.srce.hr/arhiva/8/2132/Program_Vlade_RH\%5b1\%5d.pdf (16 February 2017) 
24. Vlada Republike Hrvatske. (2011) Program Vlade Republike Hrvatske za mandat 2011. - 2015. Accessible at:

http://digured.srce.hr/arhiva/10/31637/Program\%20Vlade\%202011-2015.pdf (16 February 2017)

25. Vlada Republike Hrvatske. (2016) Program Vlade Republike Hrvatske za mandat 2016.-2020. Accessible at:

http://digured.srce.hr/arhiva/10/31637/Program_Vlada_R-_2016_2020.pdf (16 February 2017)

26. Skupština Republike Srbije. (2007) Rezolucija Narodne skupštine o zaštiti suvereniteta, teritorijalnog integriteta i ustavnog poretka Republike Srbije, Službeni glasnik Republike Srbije 125/2007. Accessible at: http://www.mfa.gov.rs/sr/index.php/component/content/article/65-zastitasuvereniteta?lang=lat (6 February 2017)

27. Skupština Republike Srbije. (2013) Sporazum između Vlade Republike Srbije i Vlade Ruske Federacije o vojnoj saradnji. Accessible at:

http://www.parlament.gov.rs/upload/archive/files/lat/pdf/predlozi_zakona/20 33-14Lat.pdf (6 February 2017)

28. Skupština Republike Srbije. (2014) Sporazum između Vlade Republike Srbije i Vlade Ruske Federacije o vojno-tehničkoj saradnji. Accessible at: http://www.parlament.gov.rs/upload/archive/files/lat/pdf/predlozi_zakona/15 00-15\%20lat.pdf (6 February 2017)

29. European Parliament. (2017) The Western Balkans. Accessible at: http://www.europarl.europa.eu/atyourservice/en/displayFtu.html?ftuld=FTU_6. 5.2.html (30 March 2017) 